\title{
Two-Level Model of Assessing Customer Satisfaction and Loyalty
}

\author{
Lukasz Skowron \\ Lublin University of Technology \\ E-Mail: lukasz.m.skowron@gmail.com \\ Marcin Gasior \\ Lublin University of Technology \\ E-Mail: gasior.m@gmail.com
}

\begin{abstract}
The researchers characterize the phenomenon of customer satisfaction, paying special attention to modern means of measuring it. Apart from presenting the main advantages and disadvantages of classic path models (ACSI and EPSI), the authors propose their own two-level conceptual model. This model allows researchers to compare the obtained results in the area of measuring customer satisfaction with other market subjects (operating both inside and outside of a given sector). Researchers will also be able to shape the phenomenon of customer satisfaction from an individualized perspective, taking particular economic markets, sectors and subjects in the research methodology into account. Thanks to the proposed model, the management of the analysed subjects offers information about the degree of customer satisfaction on two planes of complexity, enabling strategic benchmarking and facilitating the making managerial decisions, directed towards internal problems of the organization.
\end{abstract}

Keywords: Customer Satisfaction, Customer Loyalty, Path Relation Models

\section{INTRODUCTION}

In the modern economic literature by academics and practitioners on building long-lasting relationships between a company and its customers, several ways to evaluate customer satisfaction and loyalty have been proposed (see: Hill \& Alexander, 2006; Kristensen \& Westlund, 2004; Keiningham, Cooil, Aksoy, Andreassen, \& Weiner, 2007; Fornell, 2008; Ramirez \& Hachiya, 2012). The detailed description of the most widely used, advanced models (American Customer Satisfaction Index ACSI and European Performance Satisfaction Index - EPSI) which are utilized to 
measure customer satisfaction has been the topic of numerous academic studies (see: Eklöf \& Selivanova, 2008; Skowron, 2010a; 2010b; 2010c; Fornell, Rust, \& Dekimpe, 2010; Morgeson III, Mithas, Keiningham, \& Aksoy, 2011). This article presents a two-level assessment model. This model ensures collection of benchmarking data to compare customer satisfaction and its formation within subjects which are derived from different sectors of the economy, taking into consideration both the disparate specificity of the analysed enterprises and their sectors.

\section{THE ESSENCE OF RESEARCH INTO CUSTOMER SATISFACTION}

Periodic research into customer satisfaction, conducted using modern analytical tools, allows market subjects to:

- solicit customers' opinions on the quality of products/services,

- determine the main factors which influence consumers' transaction decisions,

- identify the level and scope of customers' expectations of the market offer and the enterprise itself,

- tailor the market offer to customers' needs, which is directly reflected by the level of obtained financial results,

- identify a set of critical success factors in shaping customer satisfaction,

- make an early diagnosis of the changes taking place in market preferences, which enables the enterprise to achieve the leading position in new product/organizational solutions, expected by the customers.

The goal of all studies of customer satisfaction is to enable organizations to understand the factors influencing customers' shopping decisions, to help them with making business decisions and to formulate a development strategy. If the assessment of customer satisfaction is to bring measurable market benefits, it should determine (Skowron, 2010a):

- customer priorities (which needs and expectations are important to them and to what extent),

- the margin of customer tolerance (ideal, expected and acceptable levels of quality of the offer),

- the perceived (experienced) quality of the products/services provided,

- the relationship between the achieved level of quality and the established customer priorities, as well as the quality of the competing offers.

In order for the tools which assess customer satisfaction to be accurate, a multilevel analytical model is needed. While constructing such a model, special attention should be paid to the identification of significant factors which influence customer satisfaction. A high degree of complexity (a significant number of correlative problem 
issues) as well as the multi-dimensional character of customer satisfaction constitute the main methodological problems in constructing an accurate measurement tool.

\section{DESCRIPTION OF PATH MODELLING}

Detailed descriptions of path modeling have been the subject of numerous scientific studies (see: Sheng-Hsun, Wun-hwa, \& Ming-jyh, 2006; Henseler, Ringle, \& Sinkovics, 2009; Skowron, 2010a; 2010b; 2010c; Kristensen \& Eskildsen, 2010). In this article authors presents only the basic framework of the discussed measurement technique and the results of the primary research conducted with use of the Partial Least Squares (PLS) statistical method.

To understand the main idea of the Structural Equation Modelling (path modeling) one should look at the framework presented in Figure 1.

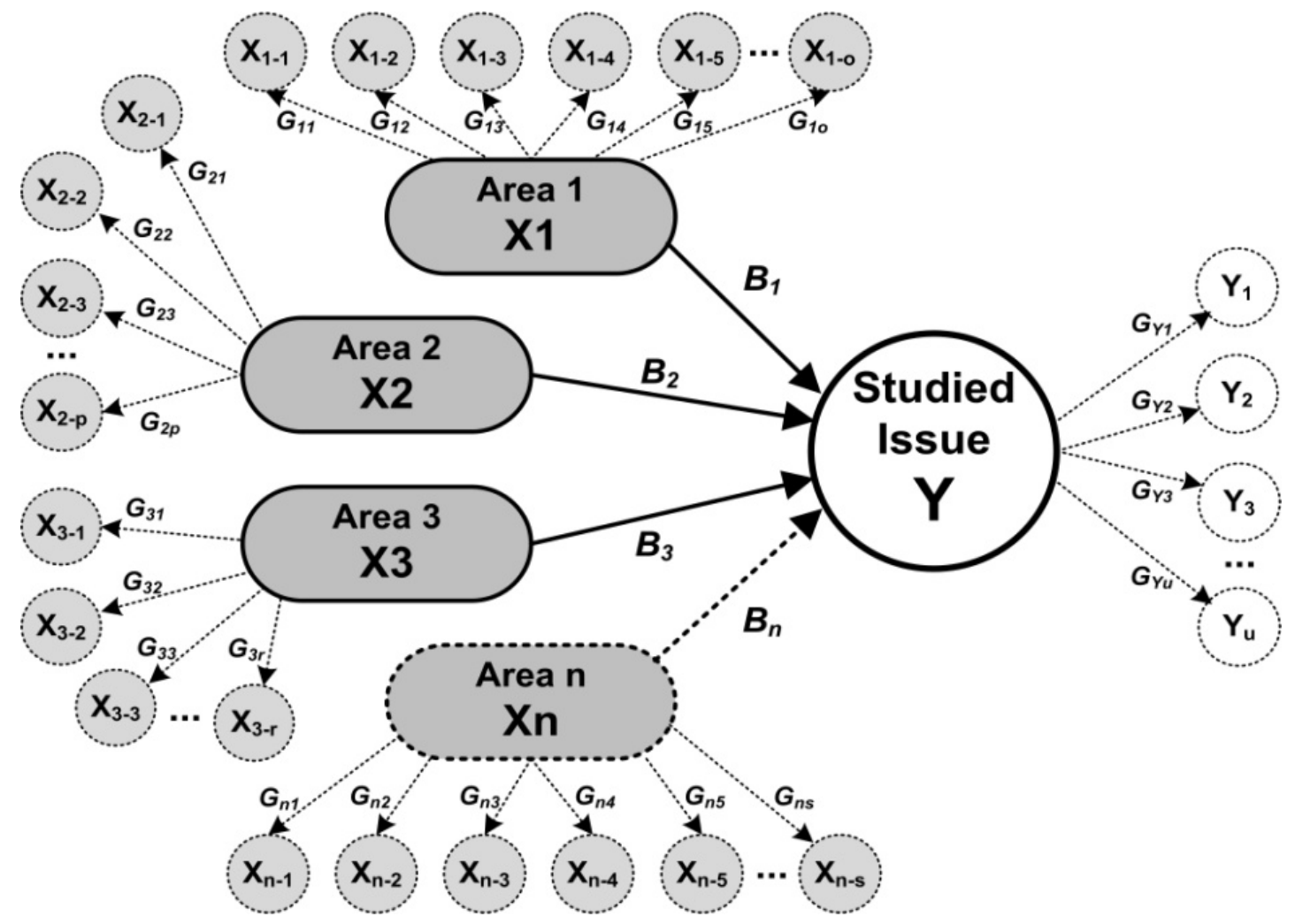

Figure 1 Basic Structural Equation Modelling (SEM) framework Source: Author's own study

According to Figure 1, the purpose of path modeling (SEM) is to present complex and non-quantifiable marketing phenomena (such as customer loyalty and satisfaction, employee motivation or brand image) in a cause-and-effect relationship. 
The advantages of the framework model are that structural equation modeling technique allows researchers to:

- determine the value/evaluation of specific areas assigned by individual respondents (Figure 1 - Y, X1, X2, X3, ..., Xn)

- defining the power of their impact on the studied phenomenon (in the case of the presented in Figure 1, the phenomenon is the issue of " $Y$ " and the impact of the areas is represented by symbols $B_{1}, B_{2}, B_{3}, \ldots, B_{n}$ )

- identify specific concepts within each of the analyzed model areas which, for the studied group of respondents, are crucial in building their opinions about a given area (e.g. in Figure 1, in the case of "Area 2" individual research questions are indicated by symbols $X_{2-1}, X_{2-2}, X_{2-3}, \ldots, X_{2-p}$ and their significance is determined by definite values assigned to symbols $G_{21}, G_{22}$, $\left.G_{23}, \ldots, G_{2 p}\right)$

In SEM, research questions take the form of the survey questions directed to the respondents in order to learn their opinion about the a marketing phenomenon. Usually the research questions are rated by respondents on a 5- or 10-point scale, where 1 is the worst rating, and 5 or 10 is the best.

By using SEM, the researcher obtains not only a response to the research questions, represented by set of mean values, as is the case with the traditional measurement tools, but, what is more important, he or she is able to evaluate the significance of different, included factors in the process. Furthermore, the path modeling methodology allows for a detailed diagnosis of the "goodness of fit" of the constructed model to the observed empirical reality at the level of both its internal consistency (AVE, Cronbachs Alfa, Composite Reliability) and external consistency (indicator $\mathrm{R}^{2}$ ).

In sum, the path models should be seen as one of the most advanced tools used for measuring complex marketing phenomena, as confirmed by its main advantages (Skowron, 2010b):

- the detailed presentation and assessment of correlative relationships in the construction of complex marketing phenomena;

- the ability to calculate the relationships between variables of the model;

- the ability to identify the main factors shaping a given phenomenon through an analysis of the overall influence;

- the possibility of measuring the model's adjustment to the observed market reality. 
The researchers treat the traditional and the most popular path models of measuring customer satisfaction and loyalty (ACSI and EPSI) as the foundation for analyzing different sectors and markets. Their main advantage is that they offer many possibilities of comparison between the enterprises and their competition. It has to be kept in mind, though, those economic subjects and sectors are characterized by diverse courses of the construction of value for the customer, resulting in various combinations of key areas of success in the analysed organizations.

In order to tailor a research model to a particular sector and market, the researcher can treat the discussed solutions as a starting point, modified to construct the marketing phenomenon in a given market, sector or organization.

It can be achieved thanks to the basic characteristic of all path models -- their modularity -- which allows the researcher to empirically modify it by adding areas which constitute vital success factors in the case of specific sectors/markets, or by increasing the number of problem issues describing a given area of the model.

\section{INDIVIDUALISATION OF PATH MEASUREMENT MODELS}

An attempt to create a more detailed measurement model which would take into account the specificity of various economic sectors and subjects in its analytical structure has been made by the Research Agency "Total Effect." Using the EPSI model, it has designed a Polish Index of Customer Satisfaction (Figure 2). The differences between the measurement tool and the model upon which it is based are the addition of "company resources" as another independent analytical module and the lack of unambiguous determination of the areas of quality. These are defined after establishing the market, sector and subject under consideration.

Such an approach results from the fact that quality is a broad and extensive concept with no single and universally accepted definition. The discussed term is defined in a different way for banking, the sector of construction services and of medical services. Each economic market, sector and subject has its own characteristics ${ }^{1}$, which should be reflected in clear and precise quality modules.

\footnotetext{
${ }^{1}$ Those features constitute the criteria of materiality considered by a potential customer in assessing a given market offer.
} 


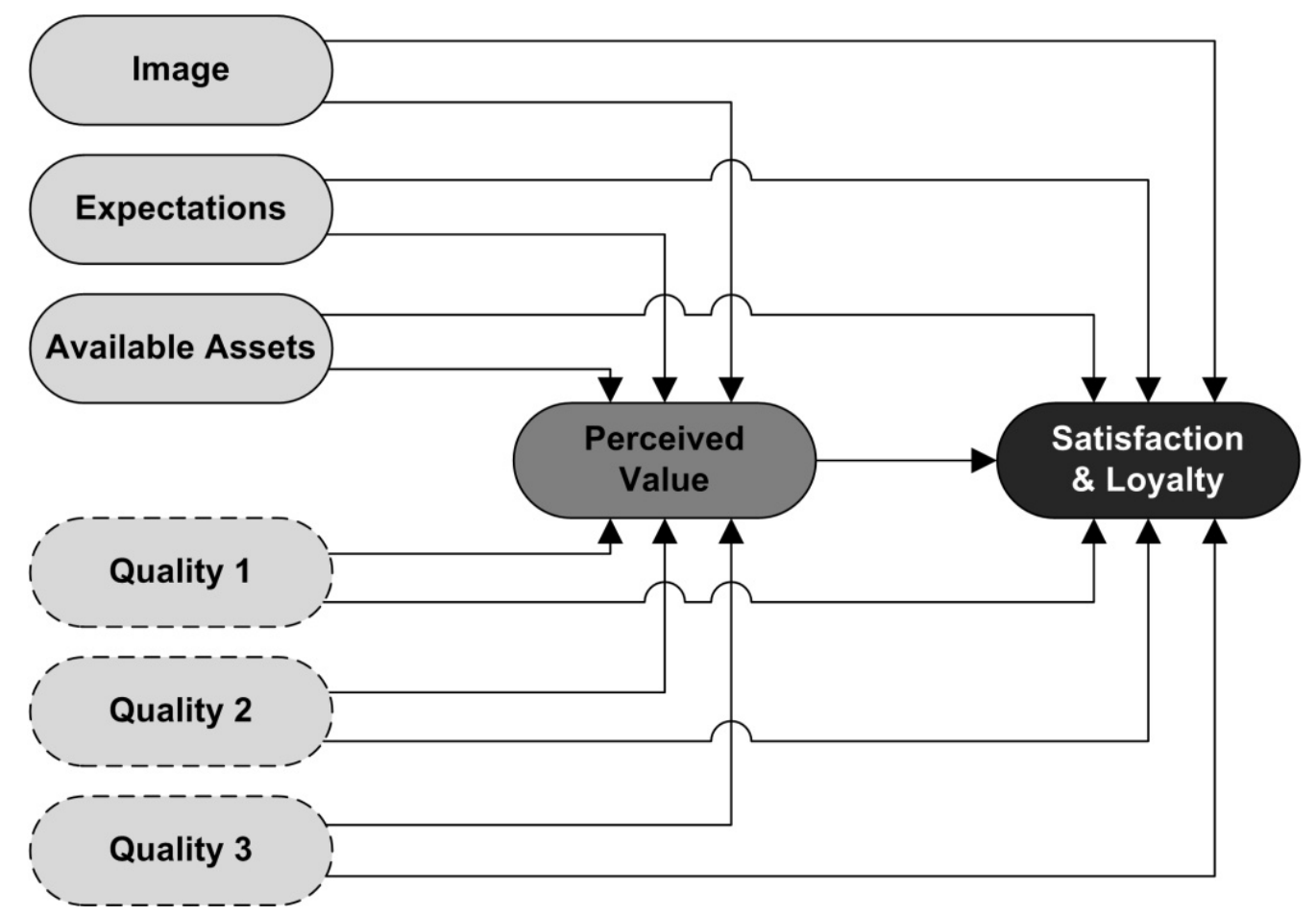

Figure 2 The model of Polish Index of Customer Satisfaction

Source: Authors' own study on the basis of the diagram published on www.totaleffect.pl website

This way of constructing a measurement tool results in the path model which presents the complexity of shaping customer satisfaction with and loyalty to an organization. Unfortunately, along with the increase in the individualization of the measurement model, the researcher loses the ability to conduct benchmarking analyses. Detailed research models are effective only for a narrow circle of subjects, while in special cases a strongly individualized research model will be an effective measurement tool only for one subject. The analytical possibilities of such a model are limited to following the changes in trends of the customer satisfaction index of an enterprise (in the reference periods in which the research was conducted), without the possibility of comparing the results with the market competition of the company. Such a limitation constitutes a fundamental strategic problem, as the lack of a point of reference makes it impossible for the researcher to determine the directions of development and strategic assumptions for the market subject.

In spite of the significant limitations of benchmarking, it has to be noted that only an individualised measurement model allows an organization to analyse the construction of the relationship between the organization and the customer. Thanks to the methodological solutions presented here, an organization gains profound knowledge about establishing the determinants of building customer satisfaction 
(including the calculation of the significance of particular problems describing each of the areas of the model).

To sum up, the methodological approach presented here allows the management to answer two fundamental questions: what is the level of customer satisfaction for our enterprise? What should be done to maximise it? Therefore, an organization which conducts a research using an individual measurement model acquires very detailed knowledge, which enables it to allocate its resources in order to construct a market offer which fulfils the needs and expectations of its customers.

\section{ORIGINAL MODEL OF MEASUREMENT TOOLS}

The advantages and disadvantages of the individualised approach to measuring customer satisfaction and loyalty cause market practitioners and scientific circles to ask a fundamental methodological question.

Is it possible to construct an analytical model that would simultaneously compare the results of customer satisfaction and loyalty indices with other subjects (both those functioning in and outside of the given economic sector) and that would take into account the specificity and diversity of particular sectors and markets? (Skowron, 2011):

To answer such a methodological quesiton, it is necessary to construct a twolevel research model which would simultaneously perform an analysis on two planes of complexity in its measuring procedure.

In each of the two assumed analytical planes of the proposed model, a researcher would acquire information about particular levels of complexity of the problem.

\section{The Internal Core of The Model}

This area of the model would contain general issues, which pose identical and constant questions for all potential research subjects. The operationalization of the questions and issues could assume a form similar to the solutions used in the most popular models used worldwide to measure customer satisfaction and loyalty (EPSI or ACSI), which would additionally increase the analytical potential of such a measurement tool. The proposed construction of the internal core of the discussed model would allow for the comparison of the results with a large number of other market subjects using these international measuring models. The result of the analyses conducted within the internal core of the model would form a general index of customer satisfaction and loyalty.

The internal core of the model is characterized by the following features (see Figure 3): 
1. It consists of 3-5 general questions describing the module of the model, in order to assess the holistic image of customer satisfaction for the analysed subjects.

2. The questions are identical for all the analysed subjects, regardless of the economic sector, which makes it possible to perform benchmarking of the results on an inter-sector and nationwide level.

3. The results allow the company to evaluate the background of its main rivals and other economic subjects (in terms of customer satisfaction and loyalty), whereas they are insufficient for making specific marketing or managerial decisions.

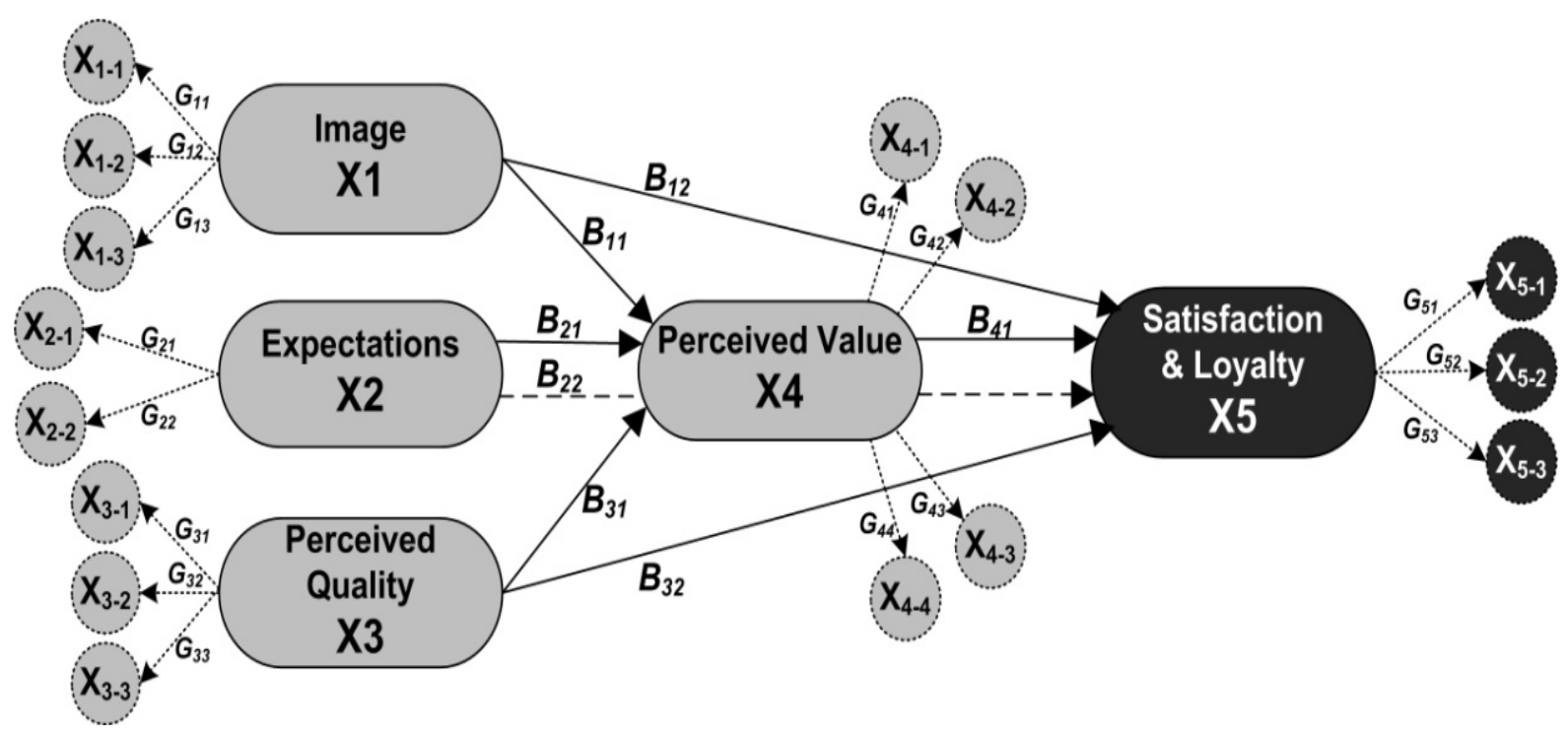

Figure 3 An Example of a General Model (of The Internal Core)

Source: Author's own study

\section{External Core of The Model}

Detailed issues are going to be placed in this area; these issues will make it possible to extend the diagnostic range with the problem questions characteristic of particular subjects, sectors and markets. As a result, the researcher will be able to create a model perfectly suited to each subject. The range and the subject matter of the detailed questions would be tailored to each subject. The discussed analytical area of the suggested model would, in the end, result in the detailed index of customer satisfaction and loyalty of the market subject. 
The external core of the model is characterized by the following features (see Figure 4):

1. It is composed of detailed questions (up to 10 questions about each of the model's modules), whose number and subject depend on the market and the sector in which a subject operates, and on that subject's internal structure.

2. The detailed questions are chosen for the subject under consideration; therefore, their results assess only the effectiveness of the organization's actions in building long-lasting relationships with the customers and cannot be used in strategic benchmarking.

3. The results make it possible to assess the construction of customer satisfaction and loyalty for an organization (and to identify the key factors of success in the construction of long-lasting relations between the company and the client).

4. The analysis makes it possible to draw conclusions which enable the organization to make marketing and management decisions.

Thanks to this analytical concept, the researcher obtains two indices of different degrees of complexity of customer satisfaction and loyalty (the overall index of satisfaction, or internal core, and the detailed index of satisfaction, or external core). Such a dualistic model of measurement makes make it possible to compare the results with other subjects (strategic benchmarking) and would present the entire multilevel construction of relations on the company-client plane, taking into account the specificity and character of each subject, sector and market.

Moreover, the external core itself can have a dual structure, encompassing questions about features and phenomena typical of a given trade (internal layer), and concerning solely the analysed enterprise (external layer). It is therefore possible to construct two categories of a model: a sector model - which ensures comparability to other enterprises of the trade, but at the same time portrays in depth the mechanisms of shaping satisfaction with and loyalty to the enterprise, and a subject model which focuses exclusively on the analysed unit.

\section{RESEARCH EXAMPLE}

The external core of the model has been widely used in market research. The authors will present the results of research conducted in Poland's banking sector. The research was carried out among a group of 2249 bank clients from 2007 to 2010. The measurement tool was the audit questionnaire. In the research the external core of the model similar to the European EPSI was used. 


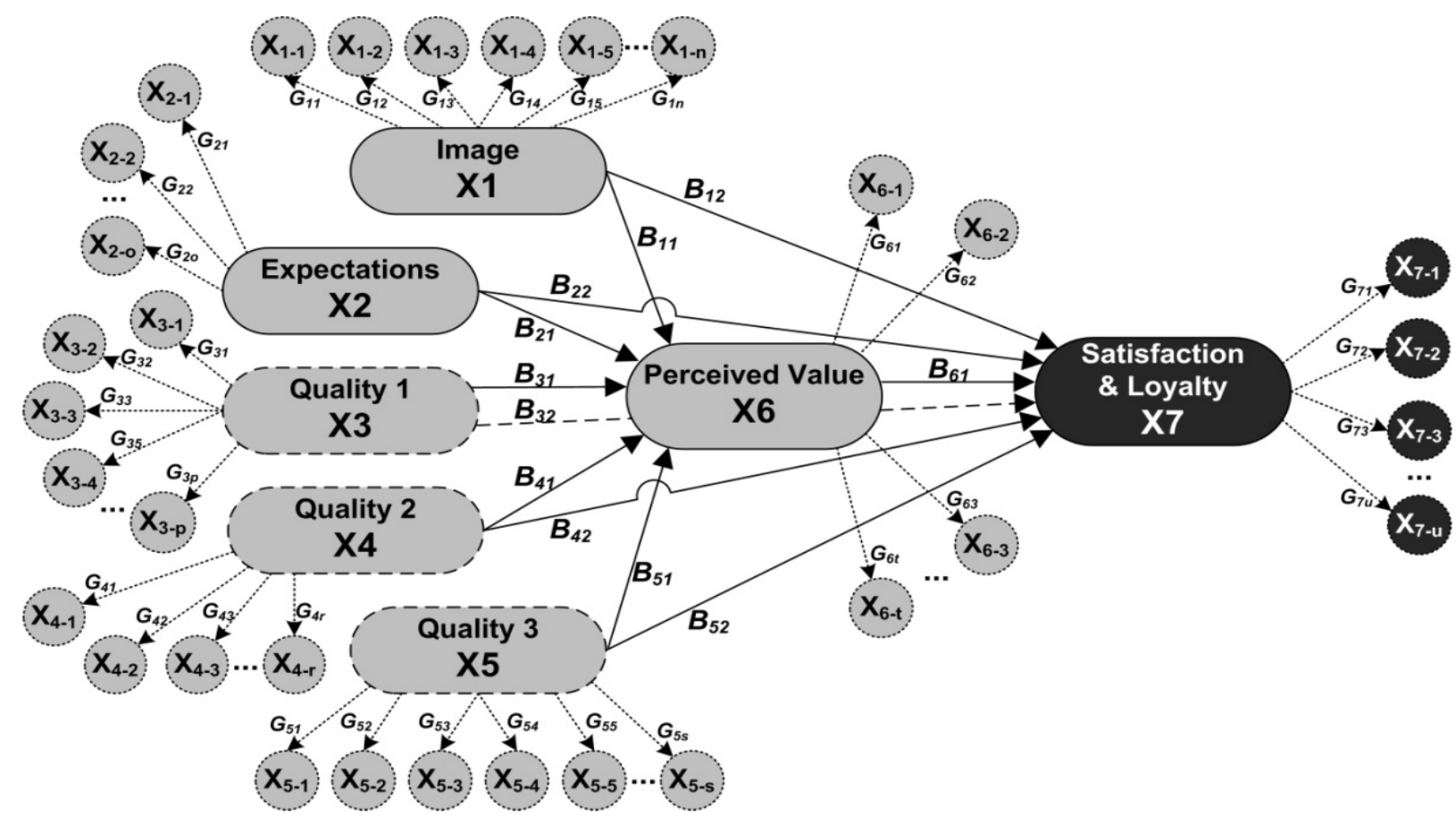

Figure 4 An Example of a Detailed Model (of The External Core)

Source: Author's own study

The differences between the Polish model and the basic one were the number of questions which describes each of the areas of the model and implementation of the three quality areas instead of two used in original EPSI framework. Table 1 presents the model.

The estimation of structural relations was carried out with the SmartPLS program. In figures 5, 6, 7 and 8 one can see estimated PLS path coefficients for years 2007, 2008, 2009, and 2010, respectively. Additionally the statistical data concerning the particular measures of the total influence (both direct and indirect - through other dependent areas) and $\mathrm{R}^{2}$ goodness of fit indicator for all time series will be presented in the table 2. A 10-point scale was used, where 1 reflects the lowest level of an answer, and 10 the highest one. Moreover, respondents could answer any question with "I do not know." 


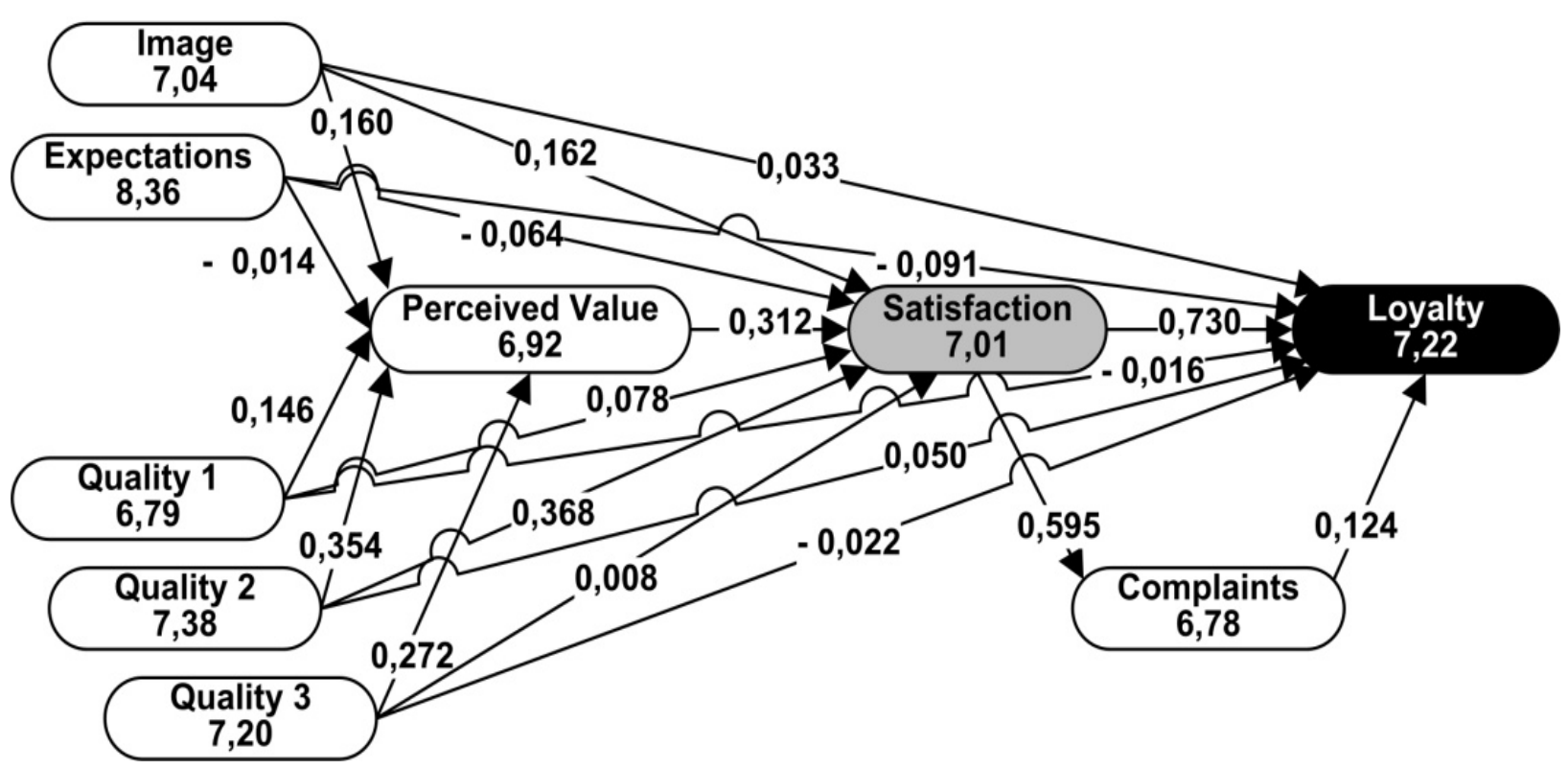

Figure 5 The model of customer loyalty in Polish banking sector for the year 2007

Source: Own work on the basis of the results of the authors' research

Table 1 The Content of The Polish Banking Sector Model

\begin{tabular}{|c|c|}
\hline Elements & Variables \\
\hline Image & $\begin{array}{l}\text { - Total image, } \\
\text { - Image of the bank from the point of view of: } \\
\text { - the bank's reliability and credibility in fulfilling promises } \\
\text { - focusing on a client's expectations and wishes } \\
\text { - confidence of actions and financial security } \\
\text { - modern technologies and the bank's development, } \\
\text { - supporting social events and initiatives }\end{array}$ \\
\hline Expectations & $\begin{array}{l}\text { - Total level of expectations } \\
\text { - Expectations concerning particular aspects: } \\
\text { - access to the bank's branches, terminals and services } \\
\text { - easy communication with the bank } \\
\text { - comfort and aesthetics of using the bank's services directly in its } \\
\text { branches } \\
\text { - a wide range of products/services and their individual adjustment } \\
\text { - professional consulting service } \\
\text { - efficiency and punctuality of services } \\
\text { - discretion and security of operations } \\
\text { - individual approach to clients } \\
\text { - level of professionalism and friendliness }\end{array}$ \\
\hline
\end{tabular}


Table 1 The Content of The Polish Banking Sector Model (continued)

\begin{tabular}{|c|c|}
\hline Elements & Variables \\
\hline $\begin{array}{l}\text { Quality } 1 \\
\text { availability } \\
\text { and comfort } \\
\text { of using } \\
\text { products and } \\
\text { services } \\
\text { offered }\end{array}$ & $\begin{array}{l}\text { - Evaluation of the conditions that bank creates for its clients, from the } \\
\text { point of view of the following elements: } \\
\text { - a sufficient number of the bank's branches, parking places and cash } \\
\text { dispensers } \\
\text { - a favorable localization of the bank and hours of the branch's work } \\
\text { - a sufficient number of service places, lack of queues } \\
\text { - the interior decoration of the branch and the client's comfort } \\
\text { - efficient phone information } \\
\text { - comfortable access to services via the Internet and the telephone in } \\
\text { favorable time } \\
\text { - clear operational procedures and information for clients }\end{array}$ \\
\hline $\begin{array}{l}\text { Quality } 2 \\
\text { the real } \\
\text { quality of a } \\
\text { given bank's } \\
\text { offer }\end{array}$ & $\begin{array}{l}\text { - Evaluation of the quality of bank's products and services concerning: } \\
\text { - speed and efficiency of service } \\
\text { - punctuality of carrying out orders } \\
\text { - speed of servicing international and inter-bank transactions } \\
\text { - the range of products and services offered } \\
\text { - adjusting the offer to a client's expectations and abilities } \\
\text { - punctuality and reliability of information } \\
\text { - efficient and clear organization of the staff's work }\end{array}$ \\
\hline $\begin{array}{l}\text { Quality } 3 \\
\text { the level of } \\
\text { customer } \\
\text { service }\end{array}$ & $\begin{array}{l}\text { - Evaluation of the level of bank's service from the point of view of: } \\
\text { - the professionalism required and the staff's appropriate knowledge } \\
\text { - the sense of security in the bank } \\
\text { - ensuring discretion } \\
\text { - the individual approach to clients } \\
\text { - the staff's behavior and friendliness }\end{array}$ \\
\hline $\begin{array}{l}\text { Perceived } \\
\text { value }\end{array}$ & $\begin{array}{l}\text { - Total perceived quality } \\
\text { - Evaluation of the transaction with the bank from the point of view of: } \\
\text { - products and services offered by the bank } \\
\text { - reliability and flawless carrying out of orders } \\
\text { - possibility of contacting the bank and accessing its services } \\
\text { - personal service and consulting } \\
\text { - other services offered by the bank (transferring data, online services, } \\
\text { security, etc.) } \\
\text { - fees and discounts proposed by the bank }\end{array}$ \\
\hline $\begin{array}{c}\text { Customer } \\
\text { satisfaction }\end{array}$ & $\begin{array}{l}\text { - The comparison with the ideal, } \\
\text { - Accordance to the expectations, } \\
\text { - Total satisfaction }\end{array}$ \\
\hline $\begin{array}{l}\text { Customer } \\
\text { loyalty }\end{array}$ & $\begin{array}{l}\text { - Willingness to purchase given products/services once again, } \\
\text { - Willingness to remain the client of the given bank } \\
\text { - Recommending given products/services to other people }\end{array}$ \\
\hline
\end{tabular}

Source: Skowron, Kristensen, 2012. 


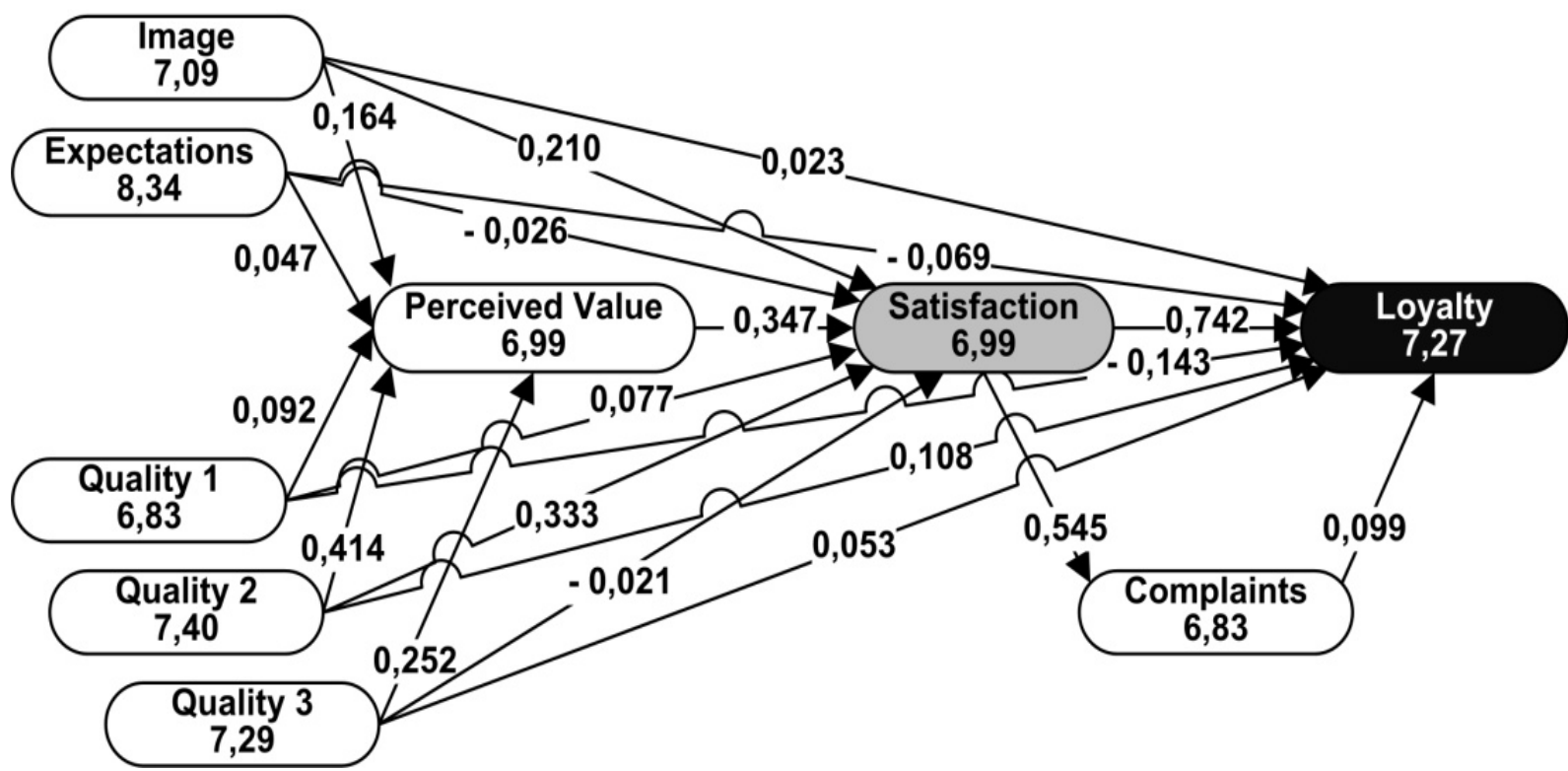

Figure 6 The Model of Customer Loyalty in Polish Banking Sector for The Year 2008 Source: Own work on the basis of the results of the authors' research

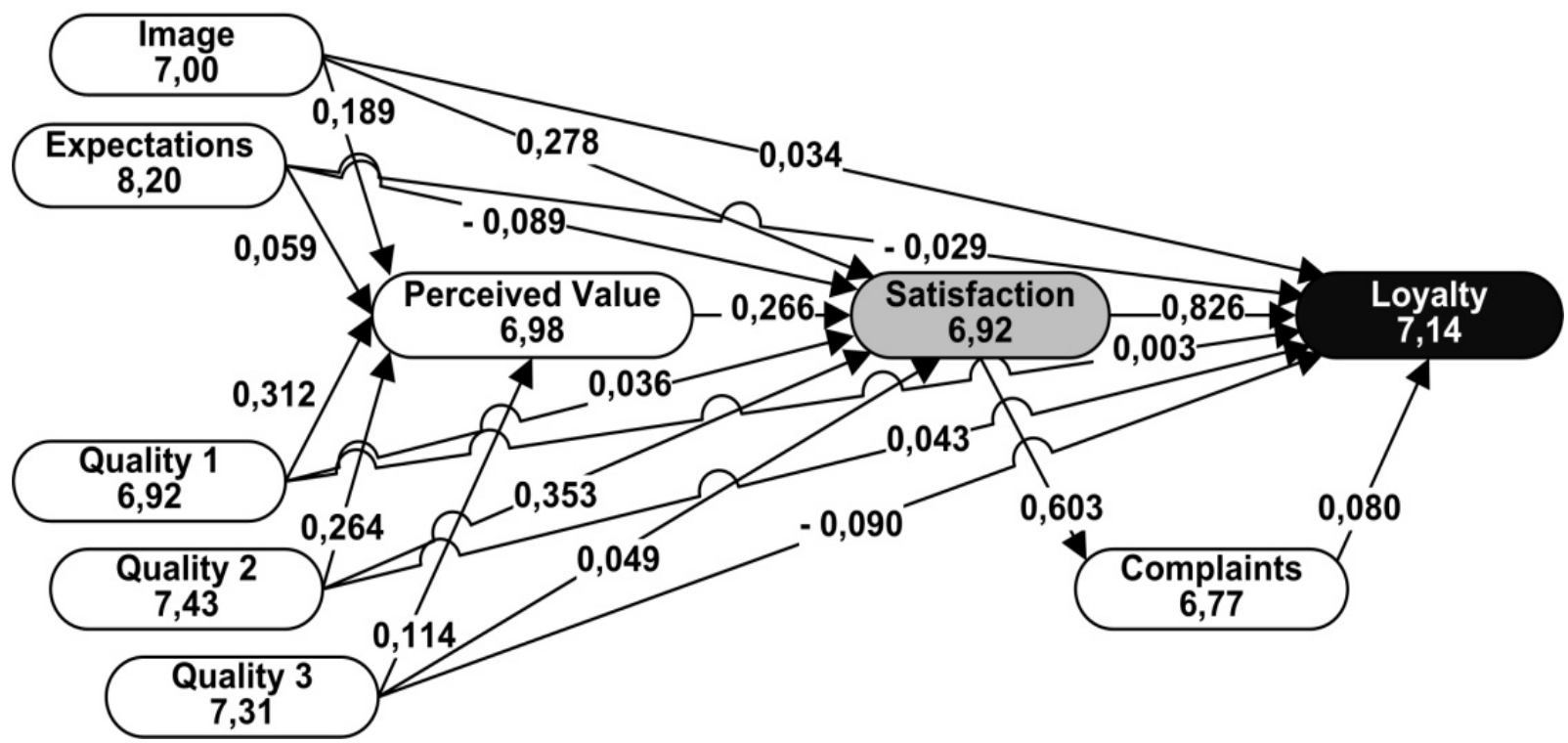

Figure 7 The Model of Customer Loyalty in Polish Banking Sector for The Year 2009 Source: Own work on the basis of the results of the authors' research 


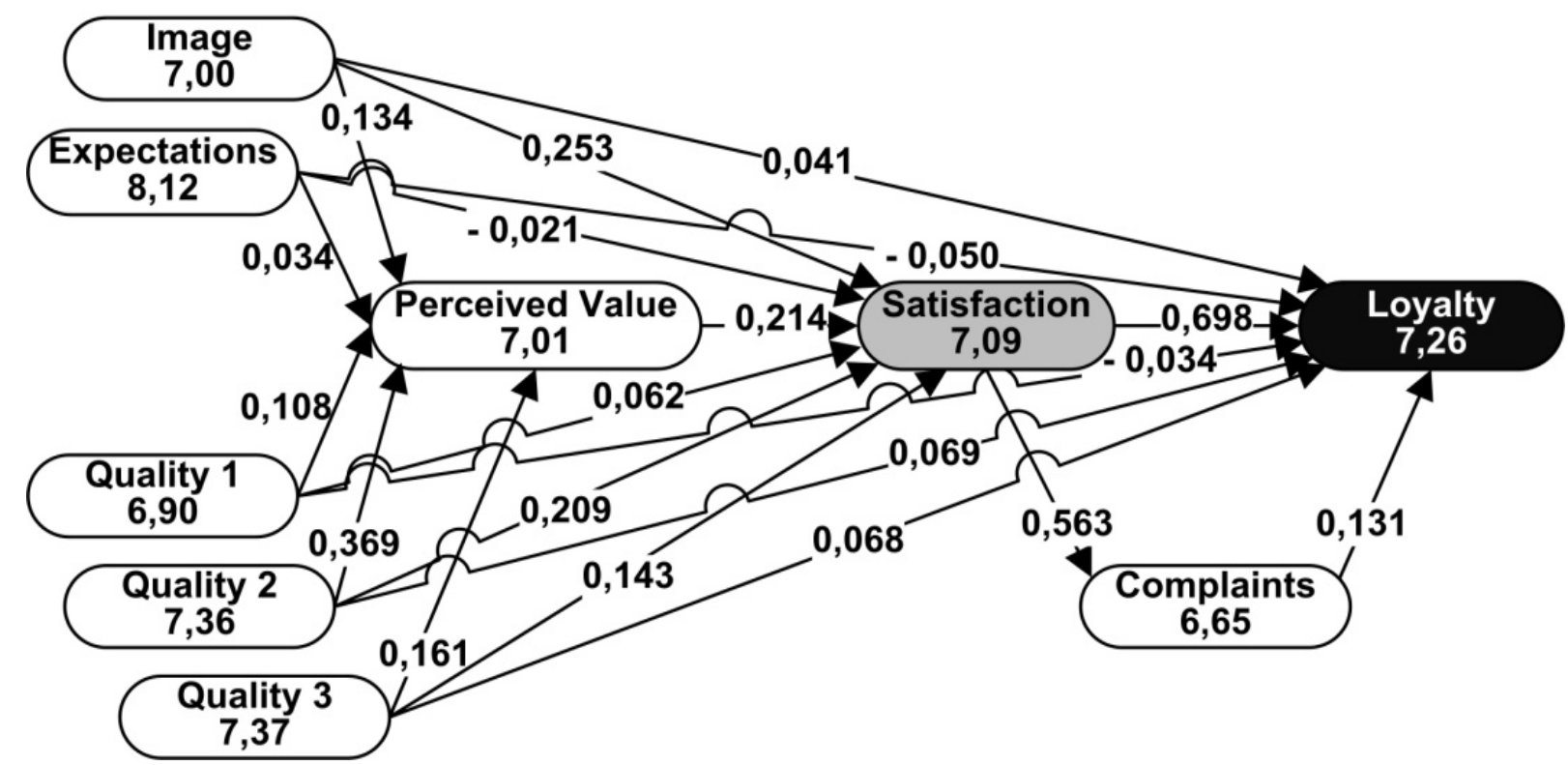

Figure 8 The Model of Customer Loyalty in Polish Banking Sector for The Year 2010 Source: Own work on the basis of the results of the authors' research

Table 2 Total Effect and $\mathrm{R}^{2}$ for The Path Dependencies in The Analysed Model Years 2007-2010

\section{$R^{2} \quad$ Total Effect $2007 / 2008 / 2009 / 2010$}

\begin{tabular}{|c|c|c|c|c|}
\hline \multirow{2}{*}{ Areas } & \multirow[b]{2}{*}{$\begin{array}{l}2007 / 2008 / \\
2009 / 2010\end{array}$} & \\
\hline & & Perceived Value & Satisfaction & Loyalty \\
\hline Image & & $\begin{array}{c}0,16 / 0,16 / \\
0,19 / 0,13 \\
\end{array}$ & $\begin{array}{c}0,21 / 0,27 / \\
0,33 / 0,28 \\
\end{array}$ & $0,20 / 0,24 / 0,32 / 0,26$ \\
\hline Expectations & & $\begin{array}{c}-0,01 / 0,05 / \\
0,06 / 0,03\end{array}$ & $\begin{array}{c}-0,07 /-0,01 / \\
-0,07 /-0,01 \\
\end{array}$ & $-0,15 /-0,08 /-0,09 /-0,06$ \\
\hline Quality 1 & & $\begin{array}{c}0,15 / 0,09 / \\
0,31 / 0,11\end{array}$ & $\begin{array}{l}0,12 / 0,11 / \\
0,12 / 0,09\end{array}$ & $0,08 /-0,06 / 0,11 / 0,03$ \\
\hline Quality 2 & & $\begin{array}{c}0,35 / 0,41 / \\
0,26 / 0,37\end{array}$ & $\begin{array}{c}0,48 / 0,48 / \\
0,42 / 0,29 \\
\end{array}$ & $0,43 / 0,49 / 0,41 / 0,30$ \\
\hline Quality 3 & & $\begin{array}{c}0,27 / 0,25 / \\
0,11 / 0,16 \\
\end{array}$ & $\begin{array}{l}0,09 / 0,07 / \\
0,08 / 0,18 \\
\end{array}$ & $0,05 / 0,11 /-0,02 / 0,21$ \\
\hline $\begin{array}{l}\text { Perceived } \\
\text { Value } \\
\end{array}$ & $\begin{array}{l}0,62 / 0,65 / \\
0,62 / 0,57 \\
\end{array}$ & & $\begin{array}{c}0,31 / 0,35 / \\
0,27 / 0,21 \\
\end{array}$ & $0,25 / 0,28 / 0,23 / 0,17$ \\
\hline Satisfaction & $\begin{array}{l}0,62 / 0,66 / \\
0,67 / 0,61 \\
\end{array}$ & & & $0,80 / 0,80 / 0,88 / 0,77$ \\
\hline Complaints & $\begin{array}{l}0,35 / 0,30 / \\
0,36 / 0,32\end{array}$ & & & $0,12 / 0,10 / 0,08 / 0,13$ \\
\hline Loyalty & $\begin{array}{l}0,69 / 0,69 / \\
0,76 / 0,73 \\
\end{array}$ & & & \\
\hline
\end{tabular}

Source: Own work on the basis of the results of the authors' research 
The analysis of the research data obtained for the entire Polish banking sector generated the following findings:

1. In the analyzed time series one may confirm (for the model used) the existence of the main triad (value - satisfaction - loyalty) the elements of which are linked by statistically strong essential relations. In addition, the area of quality 2 can be described as the main determinant of all elements of the main triad for the research samples.

2. Even though there are no significant differences in the index values of the latent variables, the building of customer loyalty in the Polish banking sector has changed slightly. The main difference is a much stronger influence (in 2009 and 2010) of the area of customer satisfaction and loyalty creation.

3. Expectations as well as availability and convenience of using banking products and services became less important for potential customers when compared to the bank's image, the quality of that bank's offer and especially its customer service.

4. In short, during financial crises banks should concentrate on building an image of being stable and well-prepared institutions. The proper communication strategy with actual and potential clients of one of the most important elements of success. Banks cannot compromise the quality of an offer, because it is still the key element of successful long-term relations with their clients.

Such a detailed analysis made with external core path modeling enables the researcher to draw precise and accurate managerial and strategic conclusions in the area of building long-term relations between banks and their clients.

\section{SUMMARY}

In today's dynamically developing market, the business success is determined by an organization's ability to build long-lasting, mutually beneficial relationships with its customers. Each organization, regardless of its size or business profile, which aims to manage relationships with its customers skillfully has to adopt effective and complex measuring methods which monitor the shaping customer satisfaction at each step.

According to the researchers, such a method ensures both a comparative analysis of the shaping of customer satisfaction in relation to the market rivals, as well as the precise adjustment of the research model to the specificity of the subject, sector and market. 
It is only through the use of complex and detailed measurements that managers can obtain data which will allow them to perform strategic benchmarking, generate a detailed description of their own consumer group, and construct relationships between the company and its customers. Moreover, the information will let the organization tailor its offer of products/services to its customers' requirements and expectations, which may result in the enterprise gaining a lasting competitive advantage on the market.

\section{ACKNOWLEDGEMENT}

Presented research is a part of a research project financed by Polish National Science Centre, decision DEC-2011/03/D/HS4/04311.

\section{REFERENCES}

Eklöf, J., \& Selivanova, I. (2008). Human Aspect in Service Quality: EPSI benchmark studies. Total Quality Management and \& Business Excellence, 19 (7-8), 827841. http://dx.doi.org/10.1080/14783360802159493

Fornell, C. (2008). The Satisfied Customer. Winners and Losers in the Battle for Buyer Preference. St. Martin's Press LLC, 175 Fifth Avenue, New York, NY 10010: Palgrave Macmillan.

Fornell, C., Rust, R.T., \& Dekimpe, M.G. (2010). The Effect of Customer Satisfaction on Consumer Spending Growth. Journal of Marketing Research, 47 (1), 28-35. http://dx.doi.org/10.1509/jmkr.47.1.28

Henseler, J., Ringle, C.M., \& Sinkovics, R.R. (2009). The use of partial least squares path modeling in international marketing. Advances in International Marketing, 20, 277-319.

Hill, N., \& Alexander, J. (2006). The Handbook of Customer Satisfaction and Loyalty Measurement. England: Gower Publishing Ltd.

Keiningham, T.L., Cooil, B., Aksoy, L., Andreassen, T. W., \& Weiner, J. (2007). The value of different customer satisfaction and loyalty metrics in predicting customer retention, recommendation, and share-of-wallet. Managing Service Quality, 17 (4), 361-384. http://dx.doi.org/10.1108/09604520710760526

Kristensen, K., \& Eskildsen, J. (2010). Design of PLS-Based Satisfaction Studies. In Handbook of Partial Least Squares. Springer Berlin Heidelberg. http://dx.doi.org/10.1007/978-3-540-32827-8_12 
Kristensen, K., \& Westlund, A.H. (2004). Performance Measurement and Business Results. Total Quality Management, 15 (5-6), 719-733. http://dx.doi.org/10.1080/14783360410001680206

Morgeson III, F.V., Mithas, S., Keiningham, T.L., \& Aksoy, L. (2011). An Investigation of the Cross-National Determinants of Customer Satisfaction. Journal of the Academy of Marketing Science, 39(2), 198-215. http://dx.doi.org/10.1007/s11747-010-0232-3

Ramirez, P.G., \& Hachiya, T. (2012). Intangible assets and market value of Japanese industries and firms. International Journal of Technology Management, 59 (1), 1-21. http://dx.doi.org/10.1504/IJTM.2012.047248

Hsu, S. H., Chen, W. H., \& Hsieh, M. J. (2006). Robustness testing of PLS, LISREL, EQS and ANN-based SEM for measuring customer satisfaction. Total Quality Management \& Business Excellence, 17(3), 355-372.

Skowron, Ł. (2010a). Modele ścieżkowe jako przykładowe metody badania satysfakcji i lojalności klientów. In Rosa, G., \& Smalec, A. (ed.): Marketing przyszłości - Trendy. Strategie. Instrumenty. Zeszyty Naukowe Uniwersytetu Szczecińskiego, 594, 495-505.

Skowron, Ł. (2010b). Satysfakcja i lojalność klienta - ujęcie modelowe i wyniki badań. In Dobiegała-Korona, B., \& Doligalski, T. (ed.): Zarzadzanie wartościa klienta. Pomiar i strategie, Chapter 11, 184-185.

Skowron, Ł. (2010c). Wykorzystanie modelu EPSI w badaniach lojalności klienta usług bankowych w wybranych krajach Unii Europejskiej. In MazurekŁopacińska, K. (ed.): Badania marketingowe - skuteczność $w$ zarzadzaniu przedsiębiorstwem, Prace Naukowe Uniwersytetu Ekonomicznego we Wrocławiu, 97, 156-168.

Skowron, Ł. (2011). Badania satysfakcji i lojalności klientów w różnych sektorach gospodarczych. Prace Naukowe Uniwersytetu Ekonomicznego we Wrocławiu, (237). 178-186.

Skowron, Ł., \& Kristensen, K. (2012). The impact of the recent banking crisis on customer loyalty in the banking sector. Developing versus developed countries, The TQM Journal, 24 (6), 480 - 497. 
